\title{
Statistical Evaluation of Middle Class in Russia
}

\author{
Elena Sibirskaya \\ Doctor of Science in Economics, Professor, Plekhanov Russian University of Economics, Moscow, Russian Federation
}

Oksana Khokhlova

Doctor of Science in Economics, Professor, Plekhanov Russian University of Economics, Moscow, Russian Federation

Nina Eldyaeva

Doctor of Science in Economics, Professor, Plekhanov Russian University of Economics, Moscow, Russian Federation

Olga Lebedinskaya

Ph.D. in Economics, Plekhanov Russian University of Economics, Moscow, Russian Federation Email: e-sibirskaya@rambler.ru

\section{Doi:10.5901/mjss.2015.v6n3s6p125}

\section{Abstract}

The arguments, whether there is a middle class in Russia, and, if it is, who can be deemed as its representatives, will probably never end. Center of discussion is situated at the merge of several disciplines. Scientists (representatives of economics, sociology, philosophy, etc.) view this problem through the prism of their knowledge - and, naturally, cannot reach the common explanation. This is normal, as different sciences have different indicators for evaluation and priorities for determining a middle class. In developed countries, middle class is an essential class, being the guarantor of social and political stability, legislator of norms of socio-economic and cultural behavior. Its representatives are characterized by independence and critical thinking, which facilitate the development of civil society and efficiency of state management. Having the role of main players in the state, investors, taxpayers, reproducing labor force, and bringing innovations into various spheres of activity, they ensure the increase of standards and quality of living of population through development of new spheres of activity in economy, through expansion of employment, modernization of functioning enterprises through development of new directions of activity, development of infrastructure necessary for modernization of state, creation of conditions for attraction and development of new resources, support for development of subjects of small and medium business through stimulation of entrepreneurial initiative, provision of sustainable and well-balanced development of economy in long-term. The larger the middle class, the better the sustainability of architecture of social order, which does not allow big conflicts between the rich and the poor. Its representatives, being the symbol of success, set the standards of consuming and are role models for many people, influencing mentality of the whole society and forming the ideas about forms of labor and leisure activity. The main duty of middle class in modern society is to facilitate the development and progress, be the bearer of social interests, cultural samples and values. Massiveness of middle class determines social stability and order in society. Still, at present, only one in seven citizen of Russia belongs to middle class. That's why the problems of its formation, as well as perfection of its internal structure, are still very topical. The most favorable social conditions for the growth of middle class may be created only by development of country in the path of innovational economy with strong regulating influence of the state.

Keywords: statistical evaluation, middle class, socio-economic development.

\section{Introduction}

According to the estimates of Institute of Sociology of Russian Academy of Sciences, Russia's middle class includes 28 million people, or appr. $20 \%$ of the Russians. Usual understanding of middle class as an intermediary layer between the poor and the rich is dangerous due to its deceitfulness, according to the head of Center for social policy of Institute of economics of Russian Academy of Sciences, Evgeniy Gontmakher (Gontmakher, 2015). Middle class is economic basis of any state, and it is unadvised to underestimate its role. For this, one must at least understand what conditions allow referring certain citizens to middle class. This task has a lot of solutions, which are satisfying in that way or another. "Expert" journal formulates this definition as the following: Russian middle class is people that, due to their education and 
professional skills were able to adapt to the conditions of modern market economy and provide their families the proper level of consuming and way of life (Expert, 2015).

The results of the survey of All-Russia Public Opinion Research Center as to what differences between groups and layers of the population are considered by the Russians to be significant, showed that the most significant are the differences between the poor, middle class, and the rich $(79 \%$ of the respondents emphasize the differences as to the income). The second place as to significance belongs to differences between population and authorities/officials (71\%). About half of the respondents (53\%) consider the social and class differences to be very important. As is well-known, the expansion of level of social differentiation beyond certain limits becomes an accelerator of social tension (Socio-economic research, 2015). Like 25 years ago, our fellow citizens complain about lack of possibilities for increasing their income: $60 \%$ in 1989 and $64 \%$ in 2014 . $24 \%$ of the respondents (19\% - earlier) state that they have good chances for improving their financial situation (Distribution of income in society: state regulation or market mechanism, 2015).

During the quarter of the century, the attitude towards the distribution of incomes in society didn't change at all: most of our fellow citizens still consider it to be unfair (completely - 51\%, or partially - 38\%). Only $5 \%$ of the respondents stick to the opposite opinion. At that, the attitude towards the state's participation in the distribution of incomes is different nowadays, than it was before: $60 \%$ think that the authorities should take certain steps as to its regulation, while before that, about $64 \%$ thought that they should not interfere. The idea of limiting the incomes of the population acquired more supporters in our days. According to recent data, the best variant is preservation of the difference of the incomes by no more than 3-4 times - it is supported by $32 \%$ of the respondents (in 1989 - only 12\%). About one fifth of the respondents $(18 \%)$ think that there should be no millionaires (27\% in 1989). One in ten (11\%) is sure that the incomes of all citizens should be equal (Distribution of incomes in society: state regulation or market mechanism, 2015).

In whole, the Russian middle class may be defined as a typological group with common social and sociopsychological characteristics, the most important of which are: comparatively high level of education and incomes, activity, independence, and orientation at stability. At that, the stability is understood primarily as stable rules of cooperation between the authorities and society.

\section{Incorporated Materials}

The sense of the term "middle class" hasn't yet received the sufficient theoretical explanation: it is associated only with certain social layers of Western society, their peculiar standards of consuming and system of values. The idea of middle class was implemented in the mass conscience of the Russians in the wide context of "westernization", as a non-reflexed attractive image. At that, the features of the middle class, which are "classical" for the West, undergo serious changes with attempts to use them for description of the similar notion in the Russian world: there is disharmony between the criteria for inclusion into middle class (primarily, according to the level of income) and absence of conditions for normal functioning of this social group (Russu, 2005).

During this research, the following methods were used: quantitative survey, including both representative survey of the population representatives in whole, and additional survey of the representatives of middle layers of society; formation of three groups of empirical data in SPSS program; building the contingency tables, multiple indices, factor analysis by varimax method, and other statistical methods of analysis.

In whole, the total volume of sample multitude consisted 1,900 people, i.e., the sample model included 2 objects (Gorshkov M. K., Tikhonova N. E., Anikin V.A. \& Latova N.V., 2014): population in whole, as the representative multitude of respondents aged 18 and older - 1,600 people; additional group of 300 people, selected by the criteria which allow meeting among them the representatives of middle class with high level of probability.

We shall use the following indicators for the research: education; society status; monthly per capita income; selfidentification.

\section{Describing the Domain}

Due to relative originality, the topic of middle class in Russia and its research are characterized by variety of different approaches and directions, together with relatively weak systematization of the received results. The basis for the research is the massive survey of the population of the RF by representative national sample, which included 1,600 people and additional group of 300 people (Gorshkov M. K., Tikhonova N. E., Anikin V.A. \& Latova N.V., 2014). For the regions of the survey, for each of which a separate sub-sample was built, in order to compare the information with the data of government statistics, 11 territorial and economic regions of Russia and Moscow were chosen. These territorial and economic regions were represented in the sample in the following way: 
1. Northern region - Arkhangelsk Oblast;

2. North-Western region - St. Petersburg and Novgorod Oblast;

3. Central region - Moscow, Ryazan, Yaroslavl, Tula Oblasts;

4. Volga-Vyatka region - Nizhny Novgorod Oblast;

5. Central Black Earth region - Voronezh Oblast;

6. Volga region - the Republic of Tatarstan, Saratov Oblast;

7. North-Caucasus region - Rostov Oblast, Stavropol Krai;

8. Ural region - Sverdlovsk and Chelyabinsk Oblasts;

9. West Siberian region - Omsk and Novosibirsk Oblasts;

10. Eat Siberian region - Irkutsk Oblast, Krasnoyarsk Krai;

11. Far Eastern region - Khabarovsk Krai;

12. Moscow.

The respondents, selected for additional group, consisted of 2 sub-groups, each of which supposed the correspondence to various criteria (Gorshkov M. K., Tikhonova N. E., Anikin V.A. \& Latova N.V., 2014): 200 people, conforming to the following requirements: higher education, non-physical type of labor, per capita family income - no less than two living wages in the region, but no less than RUB 15,000; 100 entrepreneurs that have employees, family or individual business.

\section{Tools and Procedures}

The study of middle class in modern Russia should be started from the statistical evaluation of middle class according to the indicators: education; society status; average monthly income per capita; self-identification. Let us view the representatives of middle class as to the peculiarities of the educational level. As this feature was one of the key features for defining middle class, it is obvious that educational level of its representatives will differ from the educational level of other Russians. Thus, the minimal level of education which is required for inclusion into middle class - $35 \%$ of its representatives, higher education $-65 \%$. Among the population that wasn't included into middle class, these shares are $45 \%$ and $13 \%$, correspondingly, and $42 \%$ have undergraduate education or general secondary education.

The analysis from another position shows (Gorshkov M. K., Tikhonova N. E., Anikin V.A. \& Latova N.V., 2014):

- $\quad$ higher education ensures the inclusion into middle class in $78 \%$ of cases;

- among those with general secondary education, one third (36\%) is included into middle class, $18 \%$ are in potential middle class, and almost half (46\%) belong to other population.

Thus, general secondary education, unlike the higher education, ensures the acquiring of various structural positions in society. It is necessary to dwell more on the education of unemployed representatives of middle class. As was mentioned above, for the unemployed, the membership of middle class is determined on the basis of their correspondence to three criteria: level of education; incomes; self-identification. Among the pensioners, who entered middle class, more than a half have higher education (55\%), which is not peculiar for this group in whole (thus, among the pensioners that didn't enter middle class only $17 \%$ had higher education). As to the second large group of unemployed representatives of middle class - students - most of them went through socialization in middle class families and had good chances for entering middle class in future.

The frame of middle class is consisted of, primarily, representatives of highly educated families; middle class differs a lot from other massive layers as to the level of education of parents. At that, among the Russians whose parents do not have at least general secondary education one in five enters middle class. General secondary education of one or both parents ensures entering middle class in $46 \%$ of cases, but one or both parents' having higher education raises this probability up to $69 \%$.

The process of middle class formation in Russia continues, which is proved by the fact that its many representatives' parents do not have professional education of the second and third level. Thus, conditions of initial socialization of middle class representatives distinguish them from other Russians, on the one hand. On the other hand, they differentiate two sub-groups of middle class from each other. At that, this indicator has a role of "springboard" - it reflects the level of entering that group by successful individuals from the groups that do not belong to middle class - and their children, with luck, will enter it as well.

Every person is a member of various social groups and, accordingly, the bearer of many statuses. Total statuses of a person are called the status set. The status which is considered by a person or his surroundings to be the main is called the main status. As a rule, it's the professional or family status, or status in the group, in which a person reached the most success. Statuses are divided into prescribed (given with birth) and reachable (those are acquired purposefully). The 
freer the society is, the less important are the prescribed statuses, and more important the reachable statuses, which is studied in the research of middle class.

The picture of self-evaluation of own place in the social ladder is especially interesting with the poor, though most of them (55\%) accepted the identity that corresponds to their level of life and put themselves on the three bottom steps out of possible 10 for evaluation of social status. Among them is a large group of people (43\%) which put themselves on the positions that correspond to the average levels (Figures 1).

While evaluating their status, the representatives of middle class founded on two factors - level of material security and way of life (which actually is the same as level of material security, with the deflection of the latter through the stylistic peculiarities of life of various social layers). At the same time, it should be noted that the Russian understand better and better that the issue of their status in society is not an issue of money. At any rate, five years ago, the role of material security for self-evaluation of the Russians' status was bigger (62\%), reaching almost $70 \%$.

This means that most part of the poor refuses to acknowledge themselves as a part of social outsiders. It is chiefly connected with the peculiarities of the employment of the representatives of this group - most of them consider their work to be prestigious (60\%) and interesting (67\%), and with their level of education - about $60 \%$ of those employed poor that didn't accept the identity with lower social layers, have education of the level no less than specialized secondary.

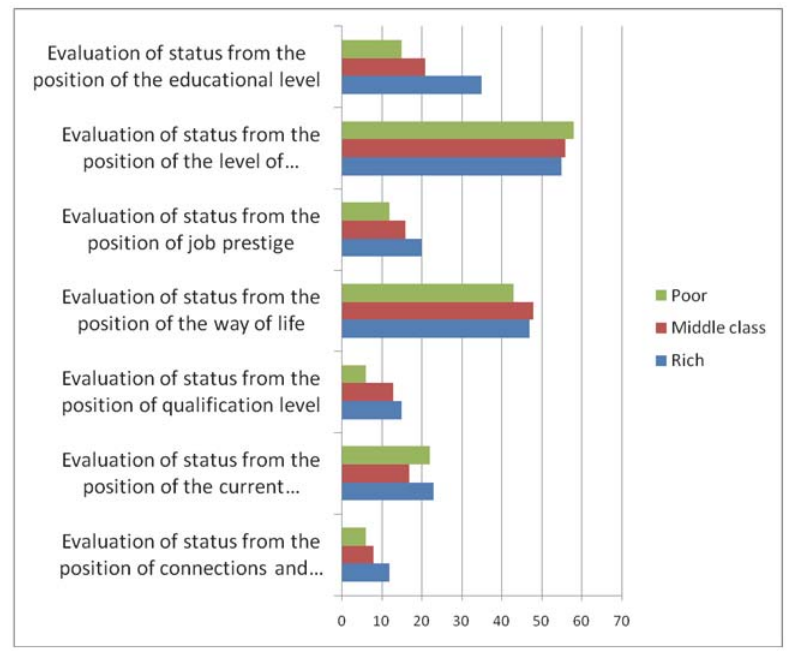

Figure 1. Data received during the study of stratificational signs

This tendency is expressed even more vividly in both subgroups of the low-income individuals and its employed individuals. The second condition, which requires special attention, is the growth of significance of the factors of education and qualification for the self-evaluation of social status, on the one hand, and peculiarities of professional activity (office and prestige of work). However, the significance of these factors for self-evaluation of the status, as the distribution of responses for them, hasn't changed for the last 5 years.

However, despite certain growth of realism, social demands of the Russians are still overstated and exceed their current status, which is actually overstated in their self-evaluations. It is completely impossible that $60 \%$ of the population would belong to middle class of society. This explains the large number of responses "satisfying" for evaluation of social status by the respondents - in whole, they evaluate their status rather high, but they would like to occupy better place in social hierarchy. The fact that even in their own retrospective evaluations of their position 5 year ago the status of most of them was relatively lower than the current one (thus, according to the respondents of this research, $21 \%$ of them were on the third position from below 5 year ago, though, as of March, 2014, only $15 \%$ of them gave the similar evaluation for their status; as to the fourth position from below, the corresponding indicators constituted $24 \%$ and $19 \%$ ), also was not capable to influence the level of their social demands.

This seemingly strange picture is caused by the fact that the starting point, or reference group, for these layers is various social groups, in relation to which they evaluate their position. For the successful, among which $70 \%$ are surrounded by the families that they consider to be rich, and which communicate mostly with the rich, not the poor families (30\% of the representatives of these layers do not have the rich in their circle of communication, $46 \%$ - do not have the poor in their circle of communication), the self-evaluations of their status (which is based, again, on the level in incomes and way of life) are shifted downwards. For the low income persons, the circle of communication of which is 
comprised mostly by the families that they themselves consider to be poor (about $60 \%$ of them have the poor in their immediate environment, the half of which is 3 and more poor families), the self-evaluation moves "ex adverso" as to the more successful layers, i.e., the starting point for them are not rich, but poor households from their acquaintances.

However, these are only general numbers for Russia, which contain different pictures for various types of households. Thus, for example, in big cities, social layers are closed and limited, and it is easier to see middle class. As a result, everyone says that they do not have the poor in their immediate environment; $53 \%$ - successful, $43 \%$ - low income, and only $36 \%$ - poor groups of society. For big, medium, and small cities, and also villages, the picture as to the presence of the poor in the immediate environment for representatives of various social groups is more ambiguous.

The model of social stratification, which formed in Russia, characterizes primarily differentiated society, in the one pole of which is small group of people that concentrated in their hands a significant part of property and income, and on the other pole - most of the country's population, living in poverty. This situation became a natural consequence of the fact that the Russian society, which is used to wage-leveling, didn't form working mechanisms of limiting the inequality.

Determining the number of the rich in modern Russia is a very complex process. This is caused both by small share of the rich in the population structure, and social barriers that limit the accessibility of this group for studying. That's why, analysis often uses indirect methods: data on taxes, level of consuming, work of various elite clubs, etc. According to various estimates, the share of the rich Russians constitutes $5-8 \%$. According to the authoritative researcher of the incomes of population, N.M. Rimashevskaya (Rimashevskaya, 2002), the grouping of population as to the income has the following form (Table 1).

Table 1. Distribution of population of Russia as to the income

\begin{tabular}{|l|c|c|}
\hline Social groups & Share in total population, $\%$ & Level of monthly income per capita, USD \\
\hline The rich and very rich & 5 & more than 2000 \\
\hline High-class & 10 & $2000-1000$ \\
\hline Middle-class & 20 & $1000-120$ \\
\hline Low-class & 30 & $120-60$ \\
\hline The poor and outcasts & 35 & less than 60 \\
\hline
\end{tabular}

According to V. Bobkov (Bobkov, 2006), who studies the issues of distribution of income in society, on the basis of the system of consumer budgets, the population of the country may be divided into four social groups: the poor; low-class; middle-class; high-class. The most important methods of studying the differentiation of population's incomes include the creation of variation series and, on their basis - of statistical series of population distribution as to the level of income per capita, which is the results of the research, ranked and grouped according to certain intervals as to the income level. The calculations of distribution of population as to the level of income per capita are conducted using the methods of imitational modeling ${ }^{1}$ by transformation of empirical distribution, received on the basis of data of selected study ${ }^{2}$, into distribution series that corresponds to the value of group attribute in general totality ${ }^{3}$.

For calculation of distribution of population as to income per capita, the data of empirical distribution and statistical evaluations, which are taken as an average for the viewed period, are used ${ }^{4}$. Under this condition, the indicators of distribution characterize the value of average income per month of the viewed period. The procedure of the distribution series creation is based in the calculation of frequencies that correspond to the given interval values of incomes per capita (variable) and the rule of lognormal distribution. However, at the evaluation of the level of differentiation of population as to level of income and income inequality, it is necessary to take into account the fact the statistics of the incomes of various groups of population leaves a lot to be desired. According to common point of view of the experts, there is no true data on the real income of the richest and poorest groups. That primarily concerns high-class groups of population which conceive illegal and half-legal income and evade taxes (Tables 3 and 4).

Lorentz concentration factor or Gini index allows evaluating the level of inequality quantitively. With equal distribution, it equals 0 ; under condition of absolute inequality, it equals 1 . For numerical evaluation of differentiation in distribution of income, the researchers also use the ratios of indicators of income between quantiles (points of distribution series which divide it in a certain proportion). They include: quartiles (quarters), deciles (tenth parts), half-deciles

1 If meeting the criteria that do not deny the relative correspondence of economic and mathematical aspects of distribution of the studied indicator of sample and general totality.

2 Beginning from 1992, the data of sampling observation of household budgets are used.

3 Per capita income, calculated in the basis of the Balance of income and expenses of population.

${ }^{4}$ At that, the empirical distribution for the viewed period is not an interval sum of frequencies of monthly distributions. 
(twentieth parts) and percentiles (hundredth parts). The decile coefficient of differentiation is calculates as ratio of levels, above and below which are the tenth parts of the total in different ends of differentiation as to the level of income.

Table 3. Population distribution as to living standards, based on the consumption budgets for 2006-2013

\begin{tabular}{|c|c|c|c|c|c|c|c|c|}
\hline & 2006 & 2007 & 2008 & 2009 & 2010 & 2011 & 2012 & 2013 \\
\hline Total population & 100 & 100 & 100 & 100 & 100 & 100 & 100 & 100 \\
\hline including population with monthly per capita income, RUB: & & & & & & & & \\
\hline up to $2,000.0$ & 4.2 & 2.6 & 1.5 & 1.0 & 0.6 & 0.4 & 0.3 & 0.2 \\
\hline $2,000.1-3,000.0$ & 7.3 & 5.1 & 3.4 & 2.5 & 1.8 & 1.3 & 1.0 & 0.7 \\
\hline $3,000.1-5,000.0$ & 18.1 & 14.2 & 11.0 & 8.8 & 7.0 & 5.6 & 4.5 & 3.3 \\
\hline $5,000.1-7,000.0$ & 16.5 & 14.5 & 12.6 & 10.9 & 9.4 & 8.1 & 6.8 & 5.6 \\
\hline $7,000.1-9,000.0$ & 12.9 & 12.5 & 11.7 & 10.8 & 9.8 & 8.9 & 7.9 & 6.8 \\
\hline $9,000.1-12,000.0$ & 13.6 & 14.4 & 14.5 & 14.2 & 13.6 & 12.9 & 12.0 & 10.8 \\
\hline $12,000.1-15,000.0$ & 8.7 & 10.1 & 10.9 & 11.3 & 11.3 & 11.3 & 10.8 & 10.3 \\
\hline $15,000.1-20,000.0$ & 8.4 & 10.5 & 12.3 & 13.3 & 14.1 & 14.6 & 14.6 & 14.5 \\
\hline $20,000.1-25,000.0$ & 4.3 & 6,0 & 7.5 & 8.6 & 9.5 & 10.2 & 10.7 & 11.2 \\
\hline $25,000.1-30,000.02)$ & 6.0 & 3.5 & 4.7 & 5.6 & 6.4 & 7.1 & 7.8 & 8.4 \\
\hline $30,000.1-35,000.03)$ & $\ldots$ & 6.6 & 3.0 & 3.7 & 4.4 & 5.0 & 5.6 & 6.3 \\
\hline $35,000.1-40,000.04)$ & $\ldots$ & $\ldots$ & 6.9 & 2.5 & 3.1 & 3.6 & 4.1 & 4.7 \\
\hline $40,000.1-50,000.05$ & $\ldots$ & $\ldots$ & $\ldots$ & 6.8 & 3.8 & 4.5 & 5.4 & 6.3 \\
\hline $50,000.1-60,000.06)$ & $\ldots$ & $\ldots$ & $\ldots$ & $\ldots$ & 5.2 & 6.5 & 3.1 & 3.8 \\
\hline more than $60,000.0$ & $\ldots$ & $\ldots$ & $\ldots$ & $\ldots$ & $\ldots$ & $\ldots$ & 5.4 & 7.1 \\
\hline
\end{tabular}

Table 4. Distribution of total volume of income and characteristics of differentiation of income of population ${ }^{5}$

\begin{tabular}{|c|c|c|c|c|c|c|c|c|}
\hline & \multirow[b]{2}{*}{$\begin{array}{c}\text { Financial income) } \\
- \text { total }\end{array}$} & \multicolumn{5}{|c|}{ Including for $20 \%$ groups of population, in \%: } & \multirow[b]{2}{*}{$\begin{array}{l}\text { Decile coefficient of } \\
\text { funds, in times }\end{array}$} & \multirow[b]{2}{*}{ Gini index } \\
\hline & & $\begin{array}{l}\text { First (with the lowest } \\
\text { income) }\end{array}$ & Second & Third & Fourth & $\begin{array}{l}\text { Fifth (with the } \\
\text { highest income }\end{array}$ & & \\
\hline 1970 & 100 & 7.8 & 14.8 & 18.0 & 22.6 & 36.8 & $\ldots$ & $\ldots$ \\
\hline 1980 & 100 & 10.1 & 14.8 & 18.6 & 23.1 & 33.4 & $\ldots$ & $\ldots$ \\
\hline 1990 & 100 & 9.8 & 14.9 & 18.8 & 23.8 & 32.7 & & - \\
\hline 1995 & 100 & 6.1 & 10.8 & 15.2 & 21.6 & 46.3 & 13.5 & 0.387 \\
\hline 1996 & 100 & 6.1 & 10.7 & 15.2 & 21.6 & 46.4 & 13.3 & 0.387 \\
\hline 1997 & 100 & 5.9 & 10.5 & 15.3 & 22.2 & 46.1 & 13.6 & 0.390 \\
\hline 1998 & 100 & 6.0 & 10.6 & 15.0 & 21.5 & 46.9 & 13.8 & 0.394 \\
\hline 1999 & 100 & 6.0 & 10.5 & 14.8 & 21.1 & 47.6 & 14.1 & 0.400 \\
\hline 2000 & 100 & 5.9 & 10.4 & 15.1 & 21.9 & 46.7 & 13.9 & 0.395 \\
\hline 2001 & 100 & 5.7 & 10.4 & 15.4 & 22.8 & 45.7 & 13.9 & 0.397 \\
\hline 2002 & 100 & 5.7 & 10.4 & 15.4 & 22.7 & 45.8 & 14.0 & 0.397 \\
\hline 2003 & 100 & 5.5 & 10.3 & 15.3 & 22.7 & 46.2 & 14.5 & 0.403 \\
\hline 2004 & 100 & 5.4 & 10.1 & 15.1 & 22.7 & 46.7 & 15.2 & 0.409 \\
\hline 2005 & 100 & 5.4 & 10.1 & 15.1 & 22.7 & 46.7 & 15.2 & 0.409 \\
\hline 2006 & 100 & 5.3 & 9.9 & 15.0 & 22.6 & 47.2 & 15.9 & 0.415 \\
\hline 2007 & 100 & 5.1 & 9.8 & 14.8 & 22.5 & 47.8 & 16.7 & 0.422 \\
\hline 2008 & 100 & 5.1 & 9.8 & 14.8 & 22.5 & 47.8 & 16.6 & 0.421 \\
\hline 2009 & 100 & 5.2 & 9.8 & 14.8 & 22.5 & 47.7 & 16.6 & 0.421 \\
\hline 2010 & 100 & 5.2 & 9.8 & 14.8 & 22.5 & 47.7 & 16.6 & 0.421 \\
\hline 2011 & 100 & 5.2 & 9.9 & 14.9 & 22.6 & 47.4 & 16.2 & 0.417 \\
\hline 2012 & 100 & 5.2 & 9.8 & 14.9 & 22.5 & 47.6 & 16.4 & 0.420 \\
\hline 2013 & 100 & 5.2 & 9.8 & 14.9 & 22.5 & 47.6 & 16.3 & 0.419 \\
\hline
\end{tabular}

${ }^{5}$ Evaluation based on the data of sampling observation of household budgets and macro-economic indicator of financial income of the population. 1) 1970-1990 - aggregate income (with the net products worth of individual farm households of population). 2) Specified data. 
For more clear information, let us present the data of coefficient in Figure 2.

According to the classification, offered for countries of Organization for Economic Cooperation and Development, Russia faces high level of inequality, as the values significantly exceed the regulation value (33-35\%).

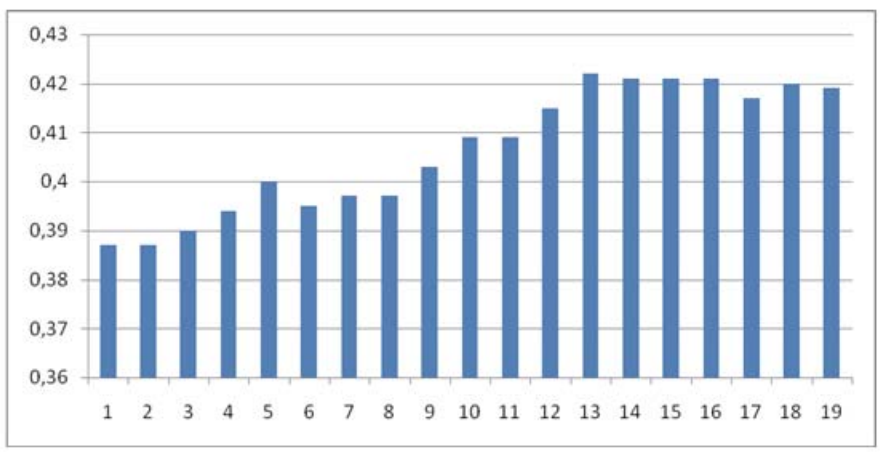

Figure 2. Estimated data of Gini index

Sum up, it may be said that there is a problem of outrunning growth of the living standards of certain groups of the Russian society. It is necessary to consider the fact that if the resources of the poor continue to reduce, the growth of anomy, degradation, marginalization of certain part of the Russian population and, consequently, of social tension, crises, and conflicts in Russian society is inevitable.

Another interesting aspect, worth analyzing with the help of the methods of self-evaluation of own position on society, is dynamics of status of representatives of modern Russian middle class as compared to statuses of their parents. On the average, middle class representatives give the higher evaluation of the status of the family, in which they were raised (5.44 points), as compared to other Russians (4.73 points). As with the evaluation of own status, these differences become more noticeable when the internal structure of middle class is taken into account.

\section{Results}

Analysis of the results of the research, conducted on the basis of methodology for distinguishing middle class, allows formulating the following general conclusions. As to its structure, middle class is not homogenous. It is possible to distinguish a stable segment in the internal structure of middle class; this segment expresses its qualitative characteristics most vividly, while reflecting the less stable environment of this segment; it includes mostly females and representatives of youth and the middle-aged. The hereditary city people are more probable to be included into it. Probability of entering middle class exceeds $50 \%$ only for those Russians whose parents (at least, one of the parents) have higher education. Own higher education also ensures entering middle class for more than a half of the Russians. At that, specialized secondary education doesn't allow its carriers to enter middle class in more than a half of cases, but increases the chances of their children of getting into middle class with time. Middle class in not homogeneous as to the level of education of parents and conditions of primary socialization, i.e., peculiarities of their cultural capital.

However, there is a substantial flow into middle class from the "outside", i.e., the flow besides the process of intergeneration production of this class (Sibirskaya E.V., 2008). First off, this relates to the periphery of middle class, which is an 'intermediate link' for it entry for representatives of the groups of population of middle class that are not included into it. This emphasizes both the influence of periphery on the image of middle class and the very close connection (including personal one) to its main segment.

During the determination of the number of modern Russian middle class, a rather demanding methodology was used; it supposed the simultaneous account of four criteria: education, monthly income per capita, non-physical labor, and self-identification.

The picture of Russian middle class reflects the peculiarities of the modern historical period of Russia's development and the model of economy that formed during the time of reforms (Gorshkov M. K., Tikhonova N. E., Anikin V.A. \& Latova N.V., 2014). Thus, it massiveness and growth are ensured by means of increase in the Russian economy of the number of labor positions for routine non-physical labor with relatively high level of wages in office work, trade, public services, and housing and utility sector. This means the increase of the share of "white collars" with average qualifications and common workers of trade and public services in middle class. Besides, middle class contains relatively 
small share of workers of quaternary sector of economy, which was peculiar for socio-professional structure of the most developed Western countries 30-40 years ago, but is uncharacteristic for modern stage of development (Rudakova O.V., Sibirskaya E.V., 2009). Fundamental expansion of middle class is possible only under conditions of diversification of economic development of the country, transition to "knowledge economy", innovational production in industry, and development of quaternary sector (Sibirskaya E.V., 2009).

In view of peculiarities of Russian middle class in the system of industrial relations and the character of work of its representatives, one may talk of the fact that this social group is a symbiosis of two rather different groups - its main segment and its environment. The main segment of middle class consists, primarily, of professionals which are employed in sectors of quaternary sphere of economy with high level of human capital. The environment is comprised of workers of non-physical labor, for which higher education is less and less characteristic.

Another special feature of evolution of image of middle class in recent years is quick reduction of its power resource, which shows the growing estrangement of its representatives from their labor activity. The share of people that are outside the limits of the Russian labor, pensionary, and social law, is very high in the main segment of middle class. These negative tendencies, certainly, require reaction from the government.

Middle class is characterized by the clear possibilities for improving one's life. At the same time, middle class is more successful as compared to other social groups, but the dynamics of its achievements is not satisfactory. Despite the fact that its breakaway from the other Russians as to the accessible achievements is large, the number of those who couldn't achieve anything significant in recent years grew by 1.4 times during last 10 years (Kostyleva L., 2010). Besides, the structure of middle class includes less of those who were able to increase the level of education or qualification over the recent years, or improve the work situation. This tendency, in case of its development, may lead not only to growth of the level of social tension in society, but also to reduction of quality of human potential of the country.

As to the plan of activities, aimed at the improvement of material security, middle class is characterized by the strategy of self-provision of food products, which is rather rare among middle class representatives, and by secondary employment on a permanent basis (which shows the demand for it in labor market, allowing its representatives choosing the most convenient types of side jobs).

Differing from other Russians due to capability to plan their lives, Russian middle class is inclined to distributing its free funds as to the time. However, unpredictability of Russian life and absence of effective financial instruments, the use of which would allow preventing the loss of value of accumulated funds, push its representatives for increasing of the current consumption to the disadvantage of investment and saving strategies.

\section{Conclusion}

The main targets in socio-economic direction of growth are increase of the share of middle class; government's control of large holders of finances and tycoons; erasing limits between white and clue collars, distinct separation of representatives of highly skilled and less skilled professionals. The results of the analysis of the information that we gathered allows distinguishing the domination vectors of values, peculiar for the viewed social stratum: stability as a guarantee of realization of plans, solving the assigned tasks within the law; freedom - primarily, freedom of choice; success - not as given success but as capability to achieve the desired goals; time - as a possibility for realization of plans; information, which allows saving time and efforts on the way to success (Sibirskaya E.V., Stroeva O.A., Khokhlova O.A. \& Oveshnikova L.V., 2014).

According to respondents, the distinctive features of the personality of representatives of middle class are the following: individualism as a way of self-expression, possibility for self-improvement and independence; optimism - not only as belief in better future but as confidence in strength and capabilities; flexibility, adaptability, capability to adapt to new realities and conditions of life; professionalism, good capacity to study; personal responsibility for own future, future of the children, welfare of the family, career growth, accommodation, etc.; social skills as a capability to start and keep necessary contacts, including business ones - as a skill to present oneself, capability for adequate self-presentation; selfesteem; purpose, high motivation for achieving the aim. Thus, representatives of middle class are people who could be described by the term "self-made persons" (Gerasimova, Gromova, Shpara, 1997). Besides, the participants of the research refer to middle class the people which are not satisfied with what has already been achieved, have active life position, including the position as to the choice of work and sphere of activity. This conclusion is implicitly proved by the hypothetical age, ascribed by the respondents to the typical representative of middle class. That is active working age after graduating when a person can realize his plans. 


\section{References}

Bobkov V. (2006). Level of social inequality. Economist. No. 3. C. 61.

Distribution of income in society: state regulation or market mechahism? (2015). URL: http://wciom.ru/index.php?id=459\&uid=115143.

Expert (2015). URL:: http://expert.ru/about/online/.

Gerasimova M.V., Gromova E.I., Shpara K.I. (1997). Self-portrait of middle class in St. Petersburg. Standard Demographic Classification. Amsterdam: ESOMAR.

Gontmakher E. (2010). Is Russian society ready for modernization, M.: Institute of sociology of RAS.

Gorshkov M. K., Tikhonova N. E., Anikin V.A. \& Latova N.V. (2014). Middle class in modern Russia: analytical report. Bulletin of institute of sociology. Moscow.

Kostyleva L. (2010). Socio-economic differentiation: (settling aspect). Socis. 9. P. 120-124.

Rimashevskaya N. (2002). Economic stratification of Russian population. Society and economy. 12. P. 9.

Rudakova O.V., Sibirskaya E.V. (2009). Economic elite of Russian society. Bulletin of Orel SIET 2. P. 110-117.

Russu O. (2005). Establishment of middle class in modern Russia: Volgograd, $164 \mathrm{p.}$

Sibirskaya E.V. (2008). Regarding the model of stratification of Russian society. Bulletin of Orel SIET. 2. P. 64-69

Sibirskaya E.V. (2009). Problems of Russian oligarchy. Bulletin of Orel SIET. 2. P. 106-109.

Sibirskaya E.V., Stroeva O.A., Khokhlova O.A. \& Oveshnikova L.V. (2014). An analysis of investment-innovation activity in Russia. - Life Sci J; 11 (7s):155-158

Socio-economic research, 2015. URL: http://wciom.ru/index.php?id=275. 
